\title{
Obituary.
}

\section{Prof. Fusakichi OMORI}

D URING the last few years we have lost three of our leading seismologists. G. W. Walker died in I921, C. G. Knott in 1922 , and, late in 1923 , Fusakichi Omori, the well-known professor of seismology in the Imperial University of Tokyo and president of the Japanese Imperial Earthquake Investigation Committee. At an early age he was fortunate in coming under the inspiring influence of John Milne and, encouraged by him, took up the study of the aftershocks of earthquakes. For a time he worked on other subjects with Milne, who left Japan in I895, and with S. Sekiya, the first professor of seismology in the Imperial University. On the death of the latter in 1896 , Omori succeeded to his chair, and about the same time became secretary of the Imperial Earthquake Investigation Committee. In this position he attained great influence. He became the natural leader in all Japanese investigations on volcanoes and earthquakes, and kept in close and friendly touch with the heads of other scientific departments. At the time of the great earthquake of September $\mathrm{I}$ he was absent from Japan, on a voyage apparently in search of health. $\mathrm{He}$ returned to the ruined city and died there on November 8 .

Few students in any branch of earth-physics have worked harder than Omori, and not many to better purpose. His papers in English alone occupy more than four thousand pages. His labours were prolonged far into the night. In one of his latest papers he describes observations on the behaviour of pheasants during earthquakes made while at work in his study at 2 A.M. He could speak and read German with ease; several of his papers are written in Italian, but the great majority were in English, not always of course with absolute precision in grammar, but never admitting any doubt as to his meaning. His papers show no evidence of wide reading, references to workers in other lands being rare or altogether absent. Thus, in a few respects, he seemed to be not quite in sympathy with recent work. If anything, he suffered from too great wealth of material, and tried to carry out work that might well have been left in the hands of assistants. We have, for example, among his papers preliminary notes on the San Francisco and Messina earthquakes, the complete reports on which were never written. $\mathrm{He}$ was one of the most kindly, modest, and upright of men, courteous with that courtesy that we now call old-fashioned, as if the manner of it were dying out from among us.

Omori's first important work was his memoir published in 1894 on the after-shocks of earthquakes, in which he stated his well-known law that governs their decline in frequency. Five years later he described his mechanically recording horizontal pendulum, an instrument thut has done useful work in Japan and elsewhere. With this and a horizontal tremor recorder he made many observations and experiments on the vibrations of brick buildings, lofty chimneys, bridges and their piers, railway trains and torpedo-boats. Several of his papers are occupied with discussions on the nature of earthquake-motion founded on the records of Japanese and distant earthquakes.
The duration of the first preliminary tremor was of special interest to him, and by its means he made several estimates of the depth of the focus in local earthquakes. His papers include many careful studies of Japanese earthquakes and of the laws which rule their distribution in space. He investigated personally the Kangra, San Francisco, and Messina earthquakes. On several occasions Omori worked at the annual and diurnal periodicity of earthquakes in Japan, and traced a relation between variations in earthquake-frequency and in barometric pressure. Also, in connexion with the same inquiries, he considered the annual variation in the height of the sea-level at different seaports in Japan.

The volcanic eruptions, as well as the earthquakes. of Japan fall within the purview of the Imperial Earthquake Investigation Committee, and Omori had several excellent opportunities of studying such eruptions from the physical point of view. The strictly geological inquiries were left in the capable hands of his colleague Prof. B. Koto. Within twelve years he published three admirable series of memoirs: the first on the eruption of the Usu-san in I9ro, with its remarkable formation of a new mountain; the second on the explosions of the Asama-yama in r9ro-r 4 ; and the third on the great eruption of the Sakura-jima in I9I4. In all three the numerous preceding and accompanying earthquakes were carefully recorded and their relations with the eruptions studied. In the Asama-yama and Sakura-jima explosions the soundareas and intervening silent zones were mapped and the distribution of the areas of multiple reports determined; while in the Sakura-jima the changes of level that accompanied and followed the great eruption were measured by re-levellings on the land and new soundings in the sea-areas. Some idea of the value of these memoirs may be gathered from the fact that the three series contain respectively 81,709 , and 520 pages, and are illustrated by $2 \mathrm{I}$, IOI, and II 4 plates.

At any time the death of our leader in seismology would have been a serious loss. But when we think of Omori's memoirs on the Sakura-jima eruption, or, as he characteristically calls them, his "modest geometrical and seismological reports," we can realise what a monograph he would have written on the most destructive earthquake known to this generation.

C. Davison.

WE regret to record the death, on January $\mathrm{I}_{4}$, of Mr. Charles Welch, formerly librarian at the Guildhall, London. Mr. Welch was born on July $2 \mathrm{I}, \mathbf{I} 848$, and served for more than forty years on the staff of the Guildhall Library, retiring in 1906. He was the author of a number of books on the history and antiquities of London, among them being "Mediæval London," written in conjunction with the late Canon Benham, and the "Modern History of London," a book of great value. He was also a contributor to the "Dictionary of National Biography" and the "Victoria County Histories." Mr. Welch was an active member of the Middlesex Archæological Society, the Society of Antiquaries, the Bibliographical Society, and the Library Association, and was connected with several of the City Companies. 